\title{
Agnieszka Czajkowska
}

\section{Człowiek i jego wolność w literaturze}

Założoną w tytule relację można rozpatrywać w odniesieniu do samej instytucji literatury ${ }^{1}$ (form wypowiedzi, jej historycznie i kulturowo określonego kształtu, związków z filozofią, ideami czy paradygmatami poznawczymi, rolą społeczną) oraz w kategoriach budowy świata przedstawionego, cech podmiotów mówiących, bohaterów i sytuacji. Można więc mówić o słowie pisanym jako wyrazie wolności (bądź zniewolenia) człowieka i jego możliwości komunikacyjnych oraz o wolności (lub niewoli) jako elementu świata w dziele literackim (kreacje podmiotu, narratora czy bohaterów, prezentowane w fabule miejsca, sytuacje i doświadczenia).

1 Wykorzystuję pojęcie instytucji literatury, ponieważ współcześnie bardzo trudno jest określić, czym w istocie jest literatura. Posiłkuję się formułą użytą w: A. Attridge, Ta dziwna instytucja zwana literatura. (Z Jacquesem Derridq rozmawia Derek Attridge), „Literatura na Świecie” 11/12 (1998), s. 177-225. Nie przyjmuję bynajmniej definicji Derridy za pewnik. Na temat niejasnego statusu literatury we współczesnej myśli teoretycznej zob. Kulturowa teoria literatury. Główne pojęcia i problemy, red. M.P. Markowski, R. Nycz, Kraków 2006; L. Nader, Afektywna historia sztuki, „Teksty Drugie” 1 (2014), s. 14-40; D. Skórczewski, Teoria - literatura - dyskurs. Pejzaż postkolonialny, Lublin 2013; H.R. Jauss, Historia literatury jako prowokacja, tłum. M. Łukasiewicz, Warszawa 1999; A. Burzyńska, M.P. Markowski, Teorie literatury XX wieku (podręcznik i antologia), Kraków 2006-2007; Kulturowa teoria literatury, t. 2: Poetyki, problematyki, interpretacje, red. T. Walas, R. Nycz, Kraków 2012. 


\section{Instytucja literatury}

Stałym motywem obecnym w historii nie tylko naszego piśmiennictwa jest napięcie pomiędzy wolnością tworzenia a przymusem, który bywa zewnętrzny i wynika z okoliczności politycznych czy określonego mecenatu, albo wewnętrzny, a więc jest odczuwany przez twórcę jako rodzaj autocenzury, która może być pochodną jego związków społecznych, obowiązujących konwencji i ograniczeń. Ilustrują ten problem liczne biografie exulów, od Owidiusza począwszy, którzy za swoje wiersze, uznane za niestosowne lub niebezpieczne z punktu widzenia władzy, płacili utratą majątków i rodziny oraz wygnaniem z ojczyzny. Ród nieprawomyślnych poetów tworzą tułający się po różnych miastach włoskich Florentczyk Dante Alighieri, łagiernik Osip Mandelsztam, wreszcie polscy zesłańcy i emigranci XIX i XX wieku, „obywatele świata” bez prawa powrotu do rodzinnego kraju. Z kolei ceną za przychylność możnego sponsora, jaką płaci poeta, jest prawdziwy bądź iluzoryczny sukces literacki oraz, co się także zdarza, drwina czy krytyka kolegów po piórze. O postawach poetów polskiego oświecenia stających w obliczu likwidacji państwa pisze Lucjan Siemieński: „Osobliwy w swoim rodzaju fenomen! Górujące talenta Krasickiego, Naruszewicza, Trembeckiego, jedynych pisarzy co mieli wpływ, a których trudno o brak polskich uczuć posądzić, nie znalazły ani jednego wyrazu potępienia za dotkliwe ciosy, owszem, wyścigały się, żeby lutnie swe dostrajać do tonu mistrza i jak on, uwielbiać Fryderyka, lub się unosić nad Semiramidą północną"2.

W oczach pisarza, tłumacza i historyka literatury, który żył w latach 1807-1877, polscy naśladowcy Woltera zamienili wolność myśli na literacki komplement, i poświęcili miłość ojczyzny dla doraźnych korzyści osobistych. Wyrazistym przykładem od-

2 L. Siemieński, Stanisław Trembecki, w: tenże, Dzieła, t. IV, Portrety literackie, Warszawa 1881, s. 262. 
dania pióra na służbę władcy i poświęcenia własnej wolności wygodnemu życiu na garnuszku bogatego sponsora jest Stanisław Trembecki. Sekretarz króla Stanisława Augusta Poniatowskiego na stare lata znalazł opiekę w Tulczynie u Szczęsnego Potockiego. Za dach nad głową odwdzięczył się magnatowi poematem Sofiówka, opisującym ogród zbudowany pod Humaniem ku czci jego trzeciej żony, słynnej Greczynki Zofii. Potocki, szczęśliwy małżonek, wcześniej wdowiec po Gertrudzie Komorowskiej, której morderstwo zlecili - jak docieka Józef Ignacy Kraszewski w Starościnie bełzkiej i opisuje Antoni Malczewski w powieści historycznej Maria - nieprzychylni mezaliansowi rodzice Franciszek Salezy i Anna Elżbieta Potoccy, już wcześniej poznał konformizm poety, skorego do komplementowania każdego, kto może się zrewanżować. Wdzięczny Trembecki, krytycznie odnosząc się w swojej poezji do konfederacji targowickiej, której czołowym uczestnikiem był Szczęsny Potocki, ,jego w swych wierszach oszczędzał"3. Nic też dziwnego, że magnatowi przydał się znakomity poeta, by mógł wychwalać w swych wierszach owianą złą sławą, znaną z rozpusty Zofię oraz jego samego, powszechnie uznawanego za zdrajcę ojczyzny.

O panegirycznym talencie innego z poetów królewskich, Adama Naruszewicza, pisał Józef Ignacy Kraszewski: „Oprócz ód, hymnów, pieśni, dytyrambów na cześć i chwałę Stanisława wysypanych pisał, co tylko królowi rozkazać się podobało: wiersze do każdego podarku królewskiego, do piesków, do faworytów; ucinki swawolne, gdy ich trzeba było, polityczne rozprawy, historyczne dowodzenia, mowy i tym podobne. [...] nie miał już czego żądać, o co prosić - ale jak doskonale, jak pokornie dziękował!!!"4.

Tamże, s. 263.

4 Cyt. za: K. Czajkowski, Pomiędzy stolicą a prowincją: topografia losów i „przygód człowieka myślacego”, w: Vzdělanec nad hranicemi „provincionality”. Uczony ponad granicami prowincjalności, red. A. Zařický, J. Davidová Glogerová, M. Závodná, Ostrawa 2014, s. 65-66. 
Przyznać jednak należy, że z punktu widzenia historii literatury wymienieni pisarze nie odczuwali pisania pod dyktando zmieniających się władców jako zniewolenia czy szczególnie dokuczliwego nacisku. Położenie piśmiennictwa w XVIII wieku (niedostępność powszechnego druku i brak masowych odbiorców) oraz panujący wówczas repertuar gatunków w sposób naturalny generowały zależność pisarza od mecenasa. Dopiero wiek XIX, wraz z rozwojem możliwości publikacji i poszerzeniem kręgu czytelniczego, utorował drogę do powstania zawodu pisarza zdolnego utrzymać się z pracy własnego pióra, co dawało możliwość wyrażania niezależnych sądów i opinii. Wzorcowym przykładem takiego artysty jest Józef Ignacy Kraszewski, masowo produkujący powieści i piszący niemal hurtowo artykuły prasowe. Przyznać jednak trzeba, że przynajmniej na początku kariery pisarz nie rezygnował $\mathrm{z}$ zabezpieczenia w postaci majątku ziemskiego, a potem rządowej posady czy też etatu redaktora gazety.

Bycie dziewiętnastowiecznym twórcą nie oznaczało bynajmniej życia w dostatku. Mimo iż wiersze Adama Mickiewicza były powszechnie znane, a autora okrzyknięto narodowym wieszczem, poeta prowadził aż do śmierci skromne życie i musiał wspomagać budżet dochodami z wykładów z literatury klasycznej na uniwersytecie w Lozannie i z literatur słowiańskich w Collége de France. Wolność słowa poety, zwłaszcza na emigracji, zawsze miała swoją cenę. Wiedział o tym bogaty z domu, giełdowy inwestor Juliusz Słowacki, miał tego świadomość w XX wieku Jan Lechoń, pracujący w dyplomacji, i Witold Gombrowicz, utrzymujący się w Argentynie z pensji urzędnika Banco Polaco.

Brak niezależności finansowej twórcy jest dokuczliwy w sytuacji rygorystycznie pojmowanej wolności słowa i rodzi problem autocenzury, która staje się rodzajem strategii pisarskiej i przybiera w historii kształty „mowy ezopowej”, ironii czy rozmaitych ról, masek i figur literackich. Taką sytuację ilustruje wiersz Zbigniewa Herberta zatytułowany Powrót prokonsula. Monologujący 
w utworze urzędnik rzymski z czasów Domicjana (I w. po Chr.), prawdopodobnie Gnejusz Juliusz Agrykola, znajdując się poza Rzymem, rozważa sytuację powrotu do stolicy imperium. Zarządca dalekiej prowincji doskonale zna mechanizmy sprawowania władzy przez cesarza, a także metody pozbywania się przez niego wrogów politycznych. Wie, że wracając na dwór, ryzykuje życiem, dlatego przybiera postawę cynika, który - w imię bezpieczeństwa i wygody - nakłada na siebie rodzaj kagańca:

trzeba będzie na nowo ułożyć się z twarzą

$\mathrm{z}$ dolną wargą by umiała powściągnąć pogardę

z oczami aby były idealnie puste ${ }^{5}$.

Autocenzura zastosowana przez Herbertowskiego bohatera w 1961 roku (utwór pochodzi z wydanego w tym roku tomu Studium przedmiotu) nie odnosiła się wyłącznie do cesarstwa rzymskiego, była przejrzystym obrazem zachowań w czasach poecie współczesnych, gdy tworząc literaturę, należało ograniczać się do dozwolonych tematów, powściągać prawdziwe uczucia i unikać otwartości w formułowaniu sądów. Mieszkaniec przedwojennego Lwowa, żołnierz Armii Krajowej zbyt wiele miał do powiedzenia na temat metod sprawowania władzy w pojałtańskiej Polsce, by pozwolić sobie na bezpośredniość i otwartość.

Figura rzymskiego patrycjusza określiła także strategię pisarską samego Herberta, który poprzez odwołanie do realiów starożytnych postaci i mitów relacjonował dzieje własnego pokolenia w rzeczywistości PRL-u.

To, co w odniesieniu do czasów komunistycznych zwykło się nazywać cenzurą lub autocenzurą i piętnować jako hamulce dla wolności słowa, nadal funkcjonuje pod postacią politycznej poprawności, pożądanej w dyskursie publicznym i warunkującej rozpowszechnianie wypowiedzi. Trudno nie uznać wiersza auto-

5 Z. Herbert, Powrót prokonsula, w: tenże, Wiersze zebrane, oprac. R. Krynicki, Kraków 2008, s. 269. 
ra Struny światła za uniwersalną obserwację mechanizmów rządzących życiem społecznym, w którym komunikacja językowa odgrywa istotną rolę.

\section{Okoliczności zewnętrzne wpływające na wypowiedź artystyczną}

Problem zaangażowania literatury wobec ideału czystości niepowiązanej z realiami życiowymi sztuki ujawnia się szczególnie podczas gwałtownych wydarzeń historycznych - rewolucji, wojen, powstań. Słowa przypisywane Cyceronowi z mowy będącej obroną Tytusa Anniusza Milona „inter arma silent Musae” (w rzeczywistości słowa mówcy brzmiały „inter arma silent leges”) niekoniecznie ilustrują sytuację literatury w „czasie marnym". Podopieczne Apolla odpowiedzialne za poezję (Kaliope, Erato, Euterpe, Melpomena i Polihymnia) wcale nie milczą podczas dziejowych przewrotów, wręcz przeciwnie, często są powoływane do służby krajowi i narodowi, przywdziewają mundury i towarzyszą frontowym walkom. Poeta-żołnierz (w wierszu Rodzicom Krzysztofa Kamila Baczyńskiego „ja, żołnierz, poeta, czasu kurz"6) jest jednym z najsilniej utrwalonych wzorów w naszej literaturze. Podporząakowanie poezji rozkazom wojskowym w czasie wojny uchodzi za zaszczyt i obowiązek.

Przykładem zaangażowania liryki do walki jest wiersz Władysława Broniewskiego Bagnet na bron, w którym autor formułuje zadania poezji na czas nadchodzącej II wojny światowej: „Dzisiaj wiersz - to strzelecki rów, / okrzyk i rozkaz: / Bagnet na broń!"7. Proroczy, pisany w kwietniu 1939 roku apel jest jedną $\mathrm{z}$ wielu realizacji postawy Tyrtajosa, który w swoich tworzonych

6 K.K. Baczyński, Rodzicom, w: tenże, Wybór poezji, oprac. J. Święch, Wrocław 1989, s. 216.

7 W. Broniewski, Bagnet na broń, w: tenże, Wybór wierszy, wstęp i oprac.

T. Bujnicki, Wrocław 2014, s. 264. 
w VII wieku przed Chrystusem utworach nawoływał do aktywności w obronie ojczyzny. Autor wiersza Bagnet na broń miał znakomitych poprzedników, z Janem Kochanowskim na czele, oraz następców, którzy jego wezwanie zrozumieli dosłownie i bez wahania oddawali Polsce własne życie.

Zarówno wojny dawnej Rzeczypospolitej, jak i powstania podczas zaborów, walki na frontach I i II wojny światowej oraz te prowadzone z bolszewikami w 1920 roku, są świadectwem, że w sytuacji zagrożenia bytu narodowego literatura chętnie rezygnuje ze swej autonomii, a pisarze zamieniają się w rzeczników postaw patriotycznych i korespondentów wojennych. Adam Grzymała-Siedlecki po czterech miesiącach praktyki wojskowej opisuje pospolite ruszenie całego narodu w 1920 roku, zaznaczając rolę literatów: „Gdy zapisuję zasługi rozmaitych warstw i stanów, dlaczegóż bym nie miał na tym miejscu wspomnieć o najbliższych, o pisarzach i artystach polskich? Gdy tylko powstała armia ochotnicza, nie było wśród nas niemal ani jednego, który by się nie oddał do dyspozycji władz wojskowych. Rozumowaliśmy krótko: «Piśmiennictwo ojczyste i sztuka narodowa były czasu niewoli tym strumieniem bytu polskiego, który ani na chwilę nie przestawał wołać o niepodległość; dziś po dwu latach państwowości wróg na nowo chce zniszczyć naszą niepodległość [...] czujemy zaszczyt spadkobierstwa po tamtych wiekach i w imię tego zaszczytu stanąć musimy do służby narodowej»"8.

Zaangażowanie literatów nie pozostaje bez konsekwencji artystycznych - taka służebność domaga się wykorzystania najprostszych, najlepiej zakorzenionych w zbiorowej świadomości form i środków wyrazu. Gdy płoną granice, nie ma miejsca na awangardowe eksperymenty i zbytnią ekspozycję "ja” twórcy. Wolność słowa - w znaczeniu swobody twórczej - bez wahania

8 A. Grzymała-Siedlecki, Cud Wisty. Wspomnienia korespondenta wojennego, Łomianki [b.r.], s. 162-163. 
schodzi na dalszy plan, by wiersz mógł bez przeszkód porywać do walki jak najwięcej odbiorców.

Wśród poezji walczącej jest także wiele przykładów, które obok tych pisanych z najszlachetniejszych pobudek - czasem nazbyt ochoczo wpisują się w nurt życia politycznego i zajmują miejsce po określonej ideologicznie stronie barykady. W efekcie dochodzi do degradacji zarówno autora, jak i jego wytworów.

Obok wierszy jawnie propagandowych, uwikłanych w zależności, są w historii literatury utwory, będące wyrazem rozgoryczenia wynikającego $\mathrm{z}$ nadmiernego zaangażowania słowa pisanego. Szczególnie gorzko brzmią w tym kontekście słowa Herberta, który w wierszu Do Ryszarda Krynickiego - list dokonuje rozrachunku z poezją swojego czasu. Utwór pochodzi z wydanego w 1983 roku w Paryżu Raportu z oblężonego miasta i jest bolesnym przypisem do stosowanej w czasie poprzedzającym wybuch Solidarności i po wprowadzeniu w Polsce stanu wojennego praktyki, która polegała na bezprecedensowym wprzęgnięciu poezji w służbę polityki. Herbert, często wbrew woli wikłany w konteksty antykomunistyczne, opowiada się za klasycznym pięknem („estetyka może być pomocna w życiu” napisze w utworze Potęga smaku), które jest jedynym gwarantem nieśmiertelności literatury. Zastosowana forma listu poetyckiego nadaje wypowiedzi charakter rozmowy mistrza z uczniem i jest jednocześnie krytyczną oceną twórczości poetów tzw. Nowej Fali, których prominentnym przedstawicielem jest adresat utworu. Pisze w nim Herbert:

Niewiele zostanie Ryszardzie naprawdę niewiele z poezji tego szalonego wieku na pewno Rilke Eliot kilku innych dostojnych szamanów którzy znali sekret zaklinania słów formy odpornej na działanie czasu bez czego nie ma fazy godnej pamiętania a mowa jest jak piasek [...] na chude barki wzięliśmy sprawy publiczne walkę z tyranią kłamstwem zapisy cierpienia 
lecz przeciwników - przyznasz - mieliśmy nikczemnie małych czy warto zatem zniżać świętą mowę do bełkotu z trybuny do czarnej piany gazet ${ }^{9}$.

Patronami poezji klasycznej, nieuwikłanej w życiowe realia, są dla Herberta Thomas S. Eliot i Reiner Maria Rilke. Świadectwem rozbratu poety z politycznymi użytkownikami jego twórczości są ostatnie wiersze, zwracające się ku uniwersalnej problematyce sensu życia człowieka, widzianego w perspektywie chrześcijańskiej. Najbardziej intymne, podejmujące dialog z Bogiem utwory Herberta wieńczą wydany w 1998 - roku śmierci - tom wierszy zatytułowany Epilog burzy. Za swój dystans do bieżącej polityki zapłacił Herbert w ostatnich latach życia cenę dla poety najwyższą. Odsunięcie dawnych przyjaciół i insynuacje dotyczące zdrowia psychicznego stały się przedmiotem komentarzy prasowych w środowisku „Gazety Wyborczej”10, a w konsekwencji niszczyły jego dobre imię i - dawnego herolda Solidarności, ikonę walki $\mathrm{z}$ komunizmem - skazywały na margines życia literackiego.

\section{Ograniczenia wynikające z „literackości”}

Literatura może być również postrzegana jako specyficzna forma ograniczająca wolność wypowiadającego się podmiotu. W potocznym mniemaniu wiersze, powieści, poematy, eseje, reportaże to „mowa wiązana”, zakładająca jakiś odgórny porządek czy wręcz rodzaj zniewolenia, kontroli i przymusu twórcy zmagającego się z żywiołem mowy. Mickiewicz w słynnym monologu Konrada z III części Dziadów deklarował brak zaufania do języka i zarzucał mu niezdolność do wyrażenia myśli i uczuć. Jako

9 Z. Herbert, Do Ryszarda Krynickiego - list, w: tenże, Wiersze zebrane, s. 464.

10 Zob. J. Siedlecka, Pan od poezji. O Zbigniewie Herbercie, Warszawa 2002, s. 366. 
uznany poeta i wieszcz narodowy, świadomy bezceremonialnych użyć własnych utworów, uznał - w myśl jednego z aforyzmów zatytułowanego Słowo i czyn - iż „trudniej dzień dobrze przeżyć, niż napisać księgę"11. W efekcie zamilkł i nad poezję przedłożył czyn, czego ostatecznym znakiem stał się w 1855 roku śmiertelny w skutkach wyjazd do Stambułu. Słowacki obrazował problem ars poetica w wydanym w 1841 roku Beniowskim, w którym, przekonany o sprawczej funkcji języka oraz doświadczony jako twórca, pisał: „Strofa winna być taktem, nie wędzidłem”"

Na potwierdzenie trudności płynących z czynności „zaklinania słów" można przytoczyć całą bibliotekę rozmaitych artes poeticae i „sztuk rymotwórczych", które od czasów Horacego (List do Pizonów) i Arystotelesa (Poetyka) uczą, jak odróżnić mowę wiązaną od zwykłej mowy, i określają rygorystyczne normy komponowania takich odświętnych wypowiedzi.

Twórczość literacka europejskiego kręgu kulturowego, obok wymienionych tradycji greckich i rzymskich, została od początku określona przez wzór Biblii i ukształtowana poprzez zawarte w niej formy wypowiedzi, gatunki, toposy, postaci bohaterów i sytuacje. Pozornie wpisywanie się w biblijną tradycję oznacza rodzaj ograniczenia wolności człowieka. Wszak sprostanie ideałowi Słowa objawionego było niezwykle trudne, niemal niemożliwe, a jako takie przez długie wieki określało ambicje i miarę pisarzy. Literaturze polskiej przyświeca wzór wdzierającego się na „skałę Kaliopy” Kochanowskiego. Dedykacja Piotrowi Myszkowskiemu z Psałterza Dawidów, z którego został wzięty parafrazowany fragment, jest wyrazem świadomości poety zmagającego się z oporem polszczyzny oraz świadectwem jego

11 A. Mickiewicz, Zdania i uwagi z dzieł Jakuba Bema, Aniła Slazzaka (Angelus Silesius) i Sę-Martina, w: tenże, Dzieła wszystkie, t. 1, cz. 3: Wiersze 1829-1855, oprac. Cz. Zgorzelski, Wrocław-Warszawa-Kraków-GdańskŁódź 1981, s. 26.

12 J. Słowacki, Beniowski. Poema, w: tenże, Poematy. Beniowski, oprac. J. Pelc, Wrocław 1952, s. 106. 
mierzenia się z wyzwaniem, jakim jest przekład na język ojczysty arcydzieła, biblijnej Księgi Psalmów. Dzieło króla Dawida jako swoisty sprawdzian talentu i formuła duchowości doczeka się po Kochanowskim wielu tłumaczen, w tym dokonanych przez tak znakomitych poetów, jak Franciszek Karpiński, Leopold Staff czy Czesław Miłosz. Do postaci biblijnego harfiarza powróci Stanisław Wyspiański, a za nim Karol Wojtyła, by ukazać najwyższą stawkę poetyckich potyczek z materią słowa.

\section{Wolność słowa zakorzeniona w Biblii}

W rzeczywistości sięganie po podstawowy wzór kultury jest miarą wolności twórcy. Poezja Mickiewicza, Słowackiego, a także Norwida, Krasińskiego i pokoleń ich następców jest głęboko zakorzeniona w Biblii. Także kariera literackich buntowników w dużej mierze zależna jest od odwołań do najbardziej utwierdzonych wartości, czerpanych z Pisma Świętego. Im gwałtowniejsza negacja, im świętsze miejsca dotknięte w geście sprzeciwu, tym większy społeczny odzew kontestacyjnej „praktyki kulturowej" i... tym głośniejsza sława autora.

Przykładem romantycznej refleksji na temat związku wolności i literatury ujmowanego w biblijnym kontekście jest poemat Cypriana Norwida Rzecz o wolności słowa. Napisany prawdopodobnie w latach 1868-1869 utwór to poetycki traktat antropologiczny (oprócz tej wartości posiada jeszcze, według autora znakomitej monografii utworu, Piotra Chlebowskiego, wymiar historiozoficzny, metaliteracki, teologiczny i genologiczno-komparatystyczny ${ }^{13}$, zaś ks. Antoni Dunajski widzi w utworze traktat

${ }_{13}$ Powołuję się na słowa Piotra Chlebowskiego wyrażone w: P. Chlebowski, Cypriana Norwida „Rzecz o wolności słowa”. Ku epopei chrześcijańskiej, Lublin 2000, s. 34. 
chrystologiczny ${ }^{14}$ ), w którym autor podejmuje polemikę z aktualnymi wówczas, opartymi na darwinowskiej teorii ewolucji koncepcjami człowieczeństwa i prezentuje własną wizję, ściśle związaną z chrześcijańskim pojmowaniem ludzkiego stworzenia. Obszerny wiersz, przygotowany początkowo jako przedmiot wystąpienia publicznego, zakłada transcendentną wizję człowieka, osiągającego pełnię istnienia w relacji z Bogiem:

Nie inaczej z Człowiekiem: gdy nań kto poziera, Jak on jest, i purpurę mu królewską zdziera, Oglądając go lichym od stopy do powiek, Jak pyłu garść rwanego wiatrem... ...cóż... tam... człowiek?!

Ale pył ów, odniesion harmonii stworzenia, Kiedy atomem swoim w gwiazdę się zamienia, I wielka rzecz stąd rośnie: co godzina, co wiek, Co Era - to mówimy wtedy: ...oto Człowiek! $!^{15}$

W wierszu Norwida miarą wartości osoby jest odniesienie do stworzonego przez Boga wszechświata, dlatego poeta krytykuje współczesne mu próby sprowadzania człowieka do elementu natury i sprzeciwia się deformacji postępu rozumianego jedynie jako rozwój własności biologicznych czy jako efekt samodzielnej, rozumowej działalności ludzi. Szukając odpowiedzi na pytanie o istotę słowa i zakres wolności człowieka jako jego współtwórcy i użytkownika, poeta dokonuje antropogenezy, sięgając do prehistorii i do Biblii. „Poetycką metodologię” Norwida określają intelektualne procedury znane z nauk przyrodniczych, technicznych (odkrycia z fizyki, chemii, biologii) czy szczególnie

${ }^{14}$ A. Dunajski, Teologiczny wymiar twórczości Norwida na przykładzie jego refleksji o pochodzeniu człowieka, w: Norwid a chrześcijaństwo, red. J. Fert, P. Chlebowski, Lublin 2002, s. 124.

15 C. Norwid, Rzecz o wolności słowa, w: tenże, Pisma wybrane, t. 2: Poematy, wybór i oprac. J.W. Gomulicki, Warszawa 1983, s. 339. 
popularnych w XIX wieku filozofii i socjologii religii. Ten solidny fundament $z$ dziedziny współczesnej wiedzy nie wyczerpuje instrumentarium poznawczego poety. Uzupełnieniem dla nich staje się historia literatury, etnografia, archeologia oraz sztuka, w tym poezja jako przykład poznania nienaukowego, intuicyjnego. Człowiek w wierszu jest przede wszystkim stworzeniem od początku określonym przez swoje ludzkie i jednocześnie transcendentne potrzeby:

Nie! Człowiek całym powstał, z u pełnie-wytwornym, I nie było mu łatwo być równie pokornym!...

Bo cały był i piękny... i upadł... ${ }^{16}$

Dane człowiekowi przez Boga Słowo - tożsame z Chrystusem - jest również od początku określone i stanowi jego istotę. Tak więc staje się ono elementem oznaczającym przynależność człowieka do Boga, a także jego współudział w tworzeniu świata poprzez daną Adamowi możliwość nazywania rzeczy po imieniu. „Natura «słowa» ludzkiego - pisze komentator poematu Piotr Chlebowski - z racji genetycznych oraz potencjalnych możliwości twórczych stanowi wierne odbicie Słowa, które było «na początku u Boga», tego Słowa, które «było [w sensie jest] Bogiem» i przez które «wszystko się stało»"17.

Norwid przekonuje, że źródłem języka ludzkiego jest Bóg, słowo jako takie jest - podobnie jak człowiek - stworzeniem doskonałym i wynoszącym niejako jego użytkownika w górę, ku niebu. Jest pośrednikiem dla Słowa objawionego i drogą do zbawienia.

Zaproponowane przez Norwida rozumienie słowa określa w konsekwencji pojmowanie jego wolności. Pisze poeta, odnosząc się do współczesnych sobie praktyk komunikacyjnych:

16 Tamże, s. 345.

17 P. Chlebowski, Cypriana Norwida „Rzecz o wolności słowa”, s. 111. 
Jaki też jest CEL-SŁOWA... jak? słow o się czy ta

W sobie samym... i dziejów jego promień cały

Rozejrzeć - mało kto jest ciekawy... zuchwały...

A jednak -

- niech no wolno ść- mo wy kto znieważy,

Ten sam, co nią pomiatał, głośno się uskarży,

I będzie mówił:

„Jako?... wszak słowo jest wolne,

$\mathrm{Te}$, co pierwej jak kwiaty sam deptałem polne,

I nad którym, śród licznych zatrudnień hałasu,

Nieco się zastanowić zbywało mi czasu!... ${ }^{18}$

Przedstawiony w poemacie krytyczny osąd Norwida dotyczy nieodpowiedzialnego, nieprzystającego do prawdziwej godności słowa używania go w powierzchownej wymianie myśli. Pozór, pośpiech, doraźny cel polemiczny, dając złudne poczucie wolności, w rzeczywistości niszczą istotę słowa i degradują relacje między ludźmi. Uniemożliwiają nie tylko autentyczną komunikację, ale też zasłaniają ostateczny jej cel - porozumienie z Bogiem:

Człowiek - który na wstępie nieustannie mówił,

Milczy i pisze naraz, gdy się zastanowił,

Naraz milczy i pisze, bo zastanowienie

Ogółu jest objęciem, więc jest określenie, [...]

Alić, gdy słowo w ślepe zmieniono narzędzie Zginął plan, opuszczono rusztowań krawędzie,

Pomięszanie wewnętrzne, znaczeń słów przemiana

I ruina, nim Babel była zbudowana! ${ }^{19}$

Biblijny obraz wieży Babel, ukazujący bezcelowość komunikacji za pomocą słowa oderwanego od swego boskiego rdzenia,

18 C. Norwid, Rzecz o wolności słowa, s. 340.

19 Tamże, s. 369. 
kontrastuje w poemacie Norwida $\mathrm{z}$ wizerunkiem katedry, budowanej na twardej opoce i będącej wynikiem systematycznego, planowego wysiłku ludzi, dążących do świętości. Przywołany w cytacie obraz jest też wynikiem obserwacji współczesnej poecie "wolności słowa”, które wraz z rozwojem druku mogło docierać do czytelnika w coraz większej liczbie książek, gazet i naukowych publikacji. Poemat Norwida odbija konflikty na tym tle, których świadkiem we Francji był poeta ${ }^{20}$.

Poemat, dobrze przyjęty przez słuchającą publiczność, w wersji wydrukowanej nie doczekał się pozytywnych recenzji. Pisał Norwid w liście do Bohdana Zaleskiego z 1871 roku: „Miałem był na ostatniej konferencji 600 osób, to jest 1200 rąk klaszczących [...] po czym miotali na mnie ślinę"21 $\mathrm{i}$ dodawał w korespondencji skierowanej do Augusta Cieszkowskiego: „[...] miałem był do s z eściu s et słuchaczy klaszczących - wydrukowano s z eśćs et egzemplarzy - żadnego nikt nie kupił"22.

Dzieje późniejszej recepcji utworu wskazują, że chrześcijańska koncepcja Słowa nie była najlepiej przyjmowana także przez czytelników końca XIX wieku i tych żyjących w następnym stuleciu. Wyjątkowy w tym kontekście okazuje się wiersz Wolność Leopolda Staffa z tomu Wysokie drzewa, opublikowanego w 1932 roku. Pisze w nim poeta, odnosząc się do ziemskiej sławy otaczającej twórców i przedkładając nad nią wolność człowieka chwalącego Boga:

Ciasno mi, Panie, na kolumnie

Pychy samotnej, gdzie choć stoję,

Trwam sztywny, jakbym leżał w trumnie,

I są spętane ruchy moje.

20 Na ten temat zob. P. Chlebowski, Cypriana Norwida „Rzecz o wolności słowa", s. 193-196.

${ }^{21}$ Cyt. za: tamże, s. 17.

22 Cyt. za: tamże. 
Wolności pragnę ponad wszystko!

Daj mi szerokie pole kołem,

Bym mógł przed Tobą klękać nisko

I jeszcze niżej hołd bić czołem ${ }^{23}$.

\section{Wolność w literaturze XX wieku}

Historia literatury dostarcza wiele przykładów dążeń do całkowitego wyzwolenia twórczości nie tylko od religijnych zobowiązań, ale też spod władzy rozumu i woli. Sprzyjał temu rozpoczęty przez rewolucję francuską demontaż tradycyjnego systemu wartości i przeciwstawienie kodeksu praw człowieka Dekalogowi. Od przełomu XIX i XX wieku rozpoczyna się w kulturze okres eksperymentów formalnych i niczym niekrępowanej ekspresji "ja” twórcy. Poeci francuskiej awangardy (wśród nich Guillaume Apollinaire) powołali do życia tzw. wiersz wolny, którego wyznacznikiem była nieregularność wynikająca z braku podziału na strofy, nieuleganie dogmatowi klasycznie rozumianego piękna i harmonii. Włoscy futuryści, działający od 1909 roku pod wodzą Filippa Tomassa Marinettiego, wprowadzili do obiegu hasło „słowa na wolności", a wraz z nim praktykę konstruowania poezji stojącej w opozycji do dotychczas obowiązujących miar i wartości. Na efekty futurystycznych postulatów nie trzeba było długo czekać - ich znakiem stała się nie tylko niczym nieograniczona swoboda artystyczna, ale także zmiany w zakresie obyczajowości i degradacja języka używanego w przestrzeni publicznej. Włoskie innowacje najlepiej zaadaptowały się w warunkach komunistycznej Rosji, prowadząc do powstania rewolucyjnych wierszy i formalno-strukturalnych teorii je uzasadniających. Wywrotowe dyrektywy do dziś kształtują formy wyrazu tzw. sztuki współ-

${ }^{23}$ L. Staff, Wolność, w: tenże, Wybór poezji, wybór i wstęp M. Jastrun, oprac. przypisów M. Bojarska, wyd. 3, Wrocław-Warszawa-KrakówGdańsk-Łódź-Wrocław 1985, s. 165. 
czesnej. Kolejne teorie badań literackich sankcjonują luzowanie rygorów estetycznych, a proces ten zaczął z czasem przybierać coraz bardziej radykalne formy, takie jak dowartościowanie kiczu czy epatowanie brzydotą i dążenie do wywołania szoku u odbiorców.

Rewolucja estetyczna ma swój odpowiednik w życiu. Realia egzystencji paryskiej dziewiętnastowiecznej bohemy na długo zdominowały kanon zachowań artystycznych, a także wprowadziły przyzwolenie na twórcze prowokacje. Przykładem są bohaterowie opery Giacoma Pucciniego Cyganeria z 1896 roku. W Polsce styl życia polegający na kontestowaniu tradycyjnej obyczajowości propagowali członkowie założonej w 1839 roku cyganerii warszawskiej. Ich kontynuacją były młodopolskie manifesty wyzwolenia spod władzy filistrów i kolejne pokolenia „kaskaderów literatury” czy „twórców awangardowych”. Takie rozumienie wolności w literaturze trwa do dziś, poszerzając dzięki masowym mediom - zakres oddziaływania eksperymentów oraz czyniąc przedmiotem wypowiedzi artystycznej kolejne, dotąd zastrzeżone, sfery życia człowieka. I chyba nikt już nie pamięta wiersza Herberta z 1969 roku, zatytułowanego Dlaczego klasycy, w którym poeta krytycznie odnosi się do trwałości sztuki współczesnej:

jeśli tematem sztuki

będzie dzbanek rozbity

mała rozbita dusza

$\mathrm{z}$ wielkim żalem nad sobą

to co po nas zostanie

będzie jak płacz kochanków

w małym brudnym hotelu

kiedy świtają tapety ${ }^{24}$.

${ }_{24}$ Z. Herbert, Dlaczego klasycy, w: tenże, Wiersze zebrane, s. 360. 


\section{Human and his freedom in literature}

The article presents a dual understanding of the relationship between freedom and literature. The first is the recognition of literature depending on external circumstances that affect the genre shape and the content conveyed in the works. An example may be engaged literature, created at a time when national existence is threatened, as well as remaining at the service of a specific ideology and giving up its autonomous properties. The second understanding of freedom and literature is the very shape of literary statements, which depends on the creator's awareness, his knowledge of normative poetics, and finally the writer's aesthetic and moral attitude. Examples are works implementing role poetics, masks, Aesop speech, etc. The author is convinced that the writer's lack of compulsion occurs when the creator strives for the truth and treats the word as a Word, a gift from God that has the dignity of a creature. An example of such a Christian conception of freedom of speech is the work by Cyprian Norwid Rzecz o wolności słowa. 